\title{
NOTES
}

\section{COMMERCIAL SPEECH RESTRICTION AND LEGAL BROTHELS: IS THERE A "VICE" EXCEPTION TO CENTRAL HUDSON'S INTERMEDIATE SCRUTINY?}

\author{
Brendan Lucas*
}

\section{INTRODUCTION}

Historically, the Supreme Court did not afford First Amendment protection for speech that was strictly commercial in nature. ${ }^{1}$ However, more recently, the Court has provided commercial speech a significant level of protection, recognizing that the free flow of commercial information is essential to the promotion of a free market because it informs the numerous private economic decisions that drive the system. ${ }^{2}$ While the Court does not apply a "strict scrutiny" First Amendment analysis to restrictions on commercial speech, it crafted an intermediate test in Central Hudson v. Public Service Commission of New York, which is now the applicable standard in evaluating the constitutionality of commercial speech restrictions. ${ }^{3}$

The Central Hudson doctrine applies not only to restrictions on commercial speech that promotes "regular" activities, like advertisements for computers or supermarkets, but also to commercial speech that promotes so\footnotetext{
2008.

1. Rubin v. Coors Brewing Co., 514 U.S. 476, 481 (1995).

2. $I d$.

3. Cent. Hudson Gas \& Elec. Corp. v. Public Serv. Comm'n, 447 U.S. 557, 566 (1980).
} 
called "vice activities," like consumption of tobacco and alcohol. ${ }^{4}$ This Note will focus on the constitutionality of restricting commercial speech concerning another so-called "vice activity," legal prostitution. Recently, in Coyote Publishing v. Miller, the United States Court of Appeals for the Ninth Circuit held that a Nevada statute, which restricted advertising for legal brothels, was constitutional under the four-pronged Central Hudson test. ${ }^{5}$ This Note will begin by tracing the development of the Supreme Court's commercial speech jurisprudence, with a particular emphasis on the "vice cases." It will then proceed to argue that, if the Supreme Court would have granted the plaintiffs' Petition for Certiorari in Coyote Publishing, the Nevada statute restricting advertisements for legal brothels would probably have been struck down as a violation of the First Amendment because it does not satisfy the intermediate scrutiny of the Central Hudson test.

\section{The Supreme Court's Commercial Speech Jurisprudence}

Until 1976, the Supreme Court held that the Constitution did not protect speech that was strictly commercial in nature. ${ }^{6}$ The Court defines commercial speech as "expression related solely to the economic interests of the speaker and its audience." Protection of commercial speech not only promotes the commercial interests of the speaker, but it also serves the best interest of society by allowing for the "fullest possible dissemination of information." Furthermore, the consumer's interest in the free flow of commercial information, on a day-to-day basis, is probably more important to that consumer than the day's most urgent political debate. ${ }^{9}$ That is, the tangible of effects of commercial speech on society, when aggregated, might have an even greater effect than political discourse. Therefore, it is extremely important to keep the channels of commercial information open, rather than allow the government to close them, because "people will perceive their own best interests only if they are well enough informed." ${ }^{" 10}$ Recognizing the importance

4. See, e.g., Lorillard Tobacco Co. v. Reilly, 533 U.S. 525, 590 (2001) (applying Central Hudson to tobacco advertisements); 44 Liquormart v. Rhode Island, 517 U.S. 484, 514 (1996) (applying Central Hudson to alcohol advertisements).

5. Coyote Publ., Inc. v. Miller, 598 F.3d 592, 610 (9th Cir. 2010).

6. Central Hudson, 447 U.S. at 561

7. Id.

8. Id. at 561-62.

9. Rubin, 514 U.S. at 481-82.

10. Central Hudson, 447 U.S. at 562 ("'P] $]$ eople will perceive their own best interests if only they are well enough informed, and ... the best means to that end is to open the channels of communication, 
of the expression of commercial speech, the Court crafted an intermediate level of scrutiny in order to evaluate the constitutionality of governmental commercial speech restrictions. ${ }^{11}$

In Central Hudson, the Court assessed the constitutionality of an action made by the Public Service Commission of New York, which banned promotional advertising for electric utility companies. ${ }^{12}$ The purpose of the prohibition was to stem the use of electricity, based on a finding that New York did not possess sufficient resources to continue furnishing electricity during the fuel shortage of $1973-74 .^{13}$ Using a newly crafted, four-part intermediate scrutiny analysis, the Court struck down the Commission's action, holding that it violated both First and Fourteenth Amendment protections. ${ }^{14}$

The first prong of the Central Hudson test is probably the simplest of the four. It involves a determination of whether the advertised activity is both lawful and truthful. ${ }^{15}$ Because the importance of commercial speech is based upon its informational value, the Court held that advertisements do not qualify for First Amendment protection unless they convey messages that accurately inform the public about lawful activity. ${ }^{16}$ Thus, the state possesses the power to ban commercial speech that is clearly deceptive or speech that promotes unlawful activity. ${ }^{17}$

If the commercial speech is neither deceptive nor related to unlawful activity, the second prong of the Central Hudson test shifts the burden to the government, which must show a "substantial" state interest that will be advanced through the speech restriction. ${ }^{18}$ Furthermore, "the regulatory technique must be in proportion to that interest." ${ }^{.19}$ In Central Hudson, the

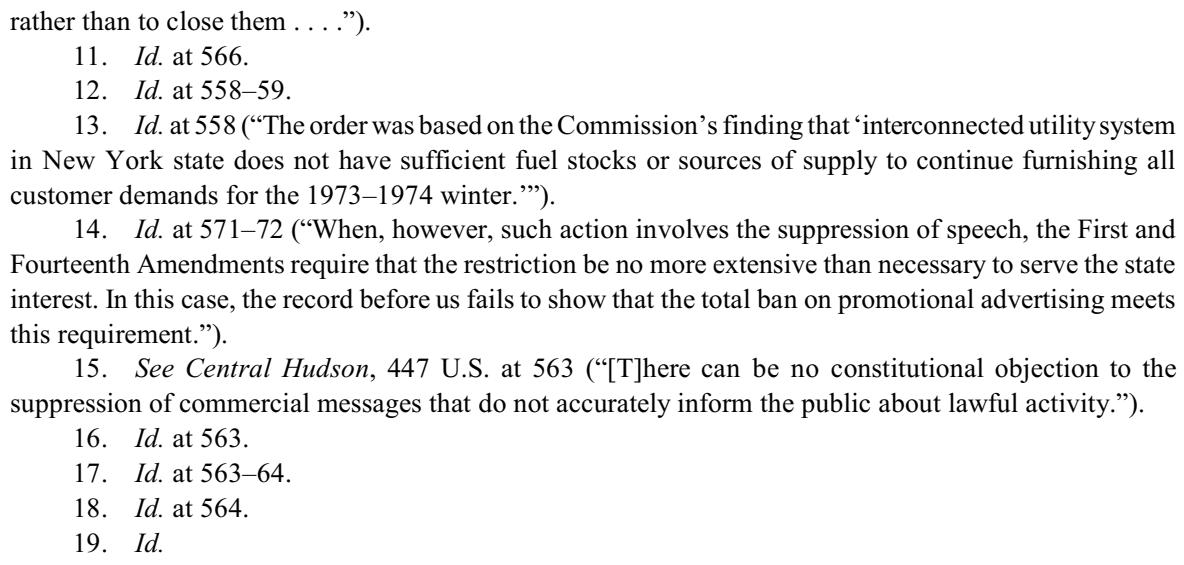

13. Id. at 558 ("The order was based on the Commission's finding that 'interconnected utility system in New York state does not have sufficient fuel stocks or sources of supply to continue furnishing all customer demands for the 1973-1974 winter."').

14. Id. at 571-72 ("When, however, such action involves the suppression of speech, the First and Fourteenth Amendments require that the restriction be no more extensive than necessary to serve the state interest. In this case, the record before us fails to show that the total ban on promotional advertising meets this requirement.").

15. See Central Hudson, 447 U.S. at 563 ("[T]here can be no constitutional objection to the suppression of commercial messages that do not accurately inform the public about lawful activity.").

16. Id. at 563 .

17. Id. at $563-64$.

18. Id. at 564 .

19. Id. 
Court held that the state's interest in conserving energy was undoubtedly substantial. ${ }^{20}$ This requirement usually does not present a very high hurdle for the government, as it can assert almost any regulatory interest related to furthering the public welfare of the state. ${ }^{21}$ For instance, the Supreme Court has held that the interest of the state in preventing minors from using tobacco is unquestionably "substantial." ${ }^{\text {"2 }}$ However, the government bears the burden of identifying the substantial interest and showing that it is real, not merely hypothetical. ${ }^{23}$ In fact, the Supreme Court has encountered interests that it did not deem "substantial." In United States v. Playboy Entertainment, Inc., the government failed to convince the Court that the possibility of children occasionally and accidentally being exposed to sexually explicit television programs was a "pervasive, nationwide problem justifying its nationwide daytime speech ban." 24

If the state's interest is deemed substantial, then it is necessary to move on to the third prong of the Central Hudson analysis. Under the third criterion, the restriction on speech must directly advance the asserted governmental interest. ${ }^{25}$ That is, any given commercial speech restriction must be shown to actually protect the interest advanced by the state. This step of the analysis involves focusing on the relationship between the state's interest and the advertising ban. ${ }^{26}$ If an advertising restriction is challenged, the government will bear the burden of showing that the regulation advances the interest "in a direct and material way. ${ }^{.27}$ The state seeking to uphold the restriction cannot satisfy this burden by mere speculation, rather, it must show that the interests it claims are real and that the restriction will, in fact, further those particular interests. ${ }^{28}$ Empirical data is not always necessary to satisfy the "directness" requirement. ${ }^{29}$ The Court has been willing to accept anecdotal evidence, history, consensus, and even "simple common sense" to show that the

20. Id. at 568 .

21. Denise S. Balboni, Note, But I Thought This Was Sin City!: Nevada's Restrictions on Advertisements for Legal Brothel Services, 7 Nev. L.J. 548, 555 (2007).

22. Lorillard, 533 U.S. at 564.

23. United States v. Playboy Entm’t Group, 529 U.S. 803, 817 (2000) (“[A] governmental body seeking to sustain a restriction on commercial speech must demonstrate that the harms it recites are real and that its restriction will in fact alleviate them to a material degree" (quoting Edenfield v. Fane, 507 U.S. 761, 770-71 (1993)).

24. Id. at $822-23$.

25. Central Hudson, 447 U.S. at 564.

26. Id. at 569 .

27. Rubin, 514 U.S. at 487 (quoting Edenfield v. Fane, 507 U.S. 761, 767 (1993)).

28. Id. (quoting Edenfield v. Fane, 507 U.S. 761, 770-71 (1993)).

29. Lorillard, 533 U.S. at 555 (citing Florida Bar v. Went For It, Inc., 515 U.S. 618, 628 (1995)). 
regulation is sufficiently direct. ${ }^{30}$ The directness requirement prevents the state from restricting "commercial speech in the service of other objectives that could not themselves justify a burden on commercial expression." ${ }^{31}$

Whether or not a challenged restriction passes the third criterion from Central Hudson can be ascertained by the overall rationality of the regulatory scheme. ${ }^{32}$ For instance, in Rubin v. Coors Brewing Co., the Supreme Court determined that a federal statute, which prohibited beer manufacturers from placing alcohol content on labels, was unconstitutional. ${ }^{33}$ In this case, the asserted governmental interest was the prevention of "strength wars," in which beer manufactures would progressively produce their beers higher and higher in alcohol content in order to attract customers. ${ }^{34}$ The Court held that the alcohol content restriction did not directly advance the interest in preventing "strength wars" because of the overall irrationality of the regulatory scheme. ${ }^{35}$ The Court deemed the scheme irrational because it failed to prohibit the display of alcohol content in advertising, which made no rational sense if the government's aim was to prevent "strength wars" between competitors. ${ }^{36}$ Furthermore, the statute seemed to encourage "strength wars" in wine sales, where the placing of alcohol content on labels was required, rather than prohibited. ${ }^{37}$ Thus, the Court held that the "directness" test was not satisfied because there was little chance the labeling restriction could directly and materially advance the government's interest, while other provisions in the statutory scheme directly counteracted its effects. ${ }^{38}$

Finally, the fourth prong of the Central Hudson test requires that the speech restriction be no more extensive than necessary to serve the asserted state interest. ${ }^{39}$ The test for determining whether a restriction passes this test is not necessarily whether it uses "the least restrictive means" available, but rather whether there exists a "reasonable fit" between the legislature's ends and the means chosen to accomplish those ends. ${ }^{40}$ Generally, a speech

30. Id

31. Rubin, 514 U.S. at 487 (quoting Edenfield v. Fane, 507 U.S. 761, 771 (1993)).

32. Id. at 488 .

33. Id. at $490-91$.

34. Id. at 488 .

35. Id. at $488-89$ ("One would think that if the Government sought to suppress strength wars by prohibiting numerical disclosures of alcohol content, it would also preclude brewers from indicating higher alcohol beverages by using descriptive terms.").

36. Id.

37. Id.

38. Id. at 489 .

39. Central Hudson, 447 U.S. at 572.

40. Lorillard, 533 U.S. at 556 ("The last step of the Central Hudson analysis 'complements' the 
restriction will be struck down if it is clearly broader than necessary to attain the stated interest. ${ }^{41}$ The government must show that it carefully crafted the restriction, calculating the costs and benefits associated with the burden imposed on free speech. ${ }^{42}$ In Lorillard Tobacco Co. v. Reilly, the Court invalidated a law that prohibited advertising of smokeless tobacco and cigars within 1,000 feet of a school. ${ }^{43}$ In doing so, the Court noted that the advertising restrictions, in practice, would constitute nearly a complete ban on the communication of truthful information by tobacco manufacturers in urban areas. ${ }^{44}$ The prohibition would prevent advertising in $87 \%$ to $91 \%$ of the greater Boston area. ${ }^{45}$ Thus, the Court held that restriction did not the satisfy the fourth prong of the Central Hudson test because the government failed to show that it had narrowly tailored the prohibition to account for the speech interests involved.

In United States v. Playboy, the Court similarly held that the complete daytime scrambling of explicit television channels was not the least restrictive means of advancing the government's interest. ${ }^{46}$ The government failed to show that allowing customers to individually block explicit channels was not an adequate alternative to the complete daytime ban. ${ }^{47}$ Therefore, in practice, when a state seeks to restrict truthful, non-misleading commercial speech, it must prove the absence of any less costly or less restrictive means. ${ }^{48}$

third step.... We have made it clear that the 'least restrictive means' is not the standard; instead, the case law requires a reasonable 'fit between the legislature's ends and the means chosen to accomplish those ends ... a means narrowly tailored to achieve the desired objective."').

41. 44 Liquormart, 517 U.S. at 497-98 (On the basis of these principles, "our early cases uniformly struck down several broadly based bans on truthful, non-misleading commercial speech, each of which served ends unrelated to consumer protection.").

42. Lorillard, 533 U.S. at 561.

43. Id. at 566 .

44. Id. at 562

45. Id.

46. Playboy Entm't Group, 559 U.S. at 822-23.

47. Id. (holding that " $[\mathrm{t}]$ here is no evidence that a well-promoted voluntary blocking provision would not be capable at least of informing parents about signal bleed (if they are not yet aware of it) and about their rights to have the bleed blocked (if they consider it a problem and have not yet controlled it themselves).").

48. Balboni, supra note 21, at 557. 


\section{There Is No Longer a "Vice Exception" to the Protection of COMMERCIAL SPEEch}

While it is clear that the Central Hudson intermediate scrutiny test applies to all truthful and non-misleading speech concerning lawful activity, it has not always been clear whether such scrutiny applies when the commercial speech concerns a lawful "vice activity," which the state has the power to prohibit entirely. In this Note, a "vice activity" refers an activity that is generally disfavored by social and cultural mores, but is nevertheless a legal activity.

In Posadas de Puerto Rico Assocs. v. Tourism Co., at issue was a law that prohibited casinos from advertising to residents of Puerto Rico. ${ }^{49}$ In 1948, Puerto Rico legalized casino gambling. ${ }^{50}$ However, in an effort to avoid the ills of casino gambling and reap only the rewards, Puerto Rico did not permit casino advertising that was likely to reach its own residents. ${ }^{51}$ The Court proceeded through the Central Hudson analysis with more deference towards the legislature than in cases that did not involve so-called "vice activities." 52

In cases where commercial speech does not concern a "vice activity," the interest of the state is not in preventing that activity itself, but in some other interest that relates to the regulated activity. ${ }^{53}$ For example, in Central Hudson, the ban on advertising for electric companies was not aimed at preventing the use of electricity in general, but rather to curb expanded usage of electricity during a historic power shortage. ${ }^{54}$ However, in Posadas, the substantial state interest was "the reduction of demand for casino gambling by the residents of Puerto Rico." ${ }^{55}$ That is, the substantial state interest was in preventing the very activity that was to be advertised. Ultimately, the Posadas Court held that Puerto Rico's “greater power to completely ban casino gambling necessarily included the lesser power to ban the advertising of casino gambling. ${ }^{, 56}$ With the holding in Posadas, it seemed that the Court had carved out a "vice exception" to Central Hudson's protection of commercial speech. That is, if a state has the power to completely ban a "vice activity,"

\footnotetext{
49. Posadas de Puerto Rico Associates v. Tourism Co., 478 U.S. 328, 330 (1986).

50. Id. at 331

51. Id. at 332 .

52. Id. at 340

53. See Central Hudson, 447 U.S. at 569 (holding that energy conservation is a substantial state interest).

54. Id. at 558

55. Posadas, 478 U.S. at 341.

56. Id. at $345-46$.
} 
then it necessarily has the "less intrusive" power to ban its advertising, even if the state has decided to make the activity lawful.

Lasting for almost ten years, this approach justified more extreme limitations on advertising for "vice activities" because state legislatures were understood to have legitimate and substantial interests in preventing access to lawful "vice activities" and products. ${ }^{57}$ However, this approach was later abandoned by the Supreme Court in 44 Liquormart $v$. Rhode Island.$^{58}$ In 44 Liquormart, a Rhode Island statute completely prohibited liquor manufacturers and vendors from advertising retail prices for alcohol "in any manner whatsoever," apart from in-store price tags.$^{59}$ Rhode Island's goal in banning advertisements for alcohol was to promote temperance by preventing retailers from price competition, and thus raising the price of alcoholic beverages. ${ }^{60}$ The Court invalidated the law and abandoned the "greater power includes the lesser power" doctrine from Posadas ${ }^{61}$ In doing so, the Court explained that it failed to see how the state's power to completely ban a commercial activity is greater than its power to ban truthful non-misleading commercial speech. ${ }^{62}$ Contrarily, the Court held that banning speech may sometimes prove far more intrusive than banning actual conduct. ${ }^{63}$ The Court noted that text of the First Amendment itself makes it clear that the Constitution presumes that attempts to regulate speech are more dangerous than attempts to regulate conduct. ${ }^{64}$ This presumption stems from the vital role that the free flow of information plays in a democratic society. ${ }^{65}$ Therefore, the Court held that the "greater power" of the state to ban the sale of liquor entirely did not necessarily entail an ability to censor truthful, non-misleading advertisements concerning its sale. ${ }^{66}$

57. Balboni, supra note 21, at 552.

58. 44 Liquormart, 512 U.S. at 508.

59. Id. at 489 .

60. Id. at 492

61. Id. at 511 ("Further considerations persuades use that the 'greater includes the lesser' argument should be rejected for the additional and more important reason that it is inconsistent with both logic and well-settled doctrine .... Although we do not dispute the proposition that greater powers include lesser ones, we fail to see how that syllogism requires the conclusion that the State's power to regulate commercial activity is 'greater' than its power to ban truthful, nonmisleading, speech.").

62. $I d$.

63. $I d$.

64. Id. at 512 (noting that "the First Amendment directs that government may not suppress speech as easily as it may suppress conduct and that speech restrictions cannot be treated as simply another means that government may use to achieve its ends").

65. Id.

66. 44 Liquormart, 512 U.S. at 513-14. 
Furthermore, the Court rejected wholesale Puerto Rico's contention in Posadas that any type of "vice exception" should exist to the Central Hudson analysis. ${ }^{67}$ First, the Court's holding in Rubin v. Coors made clear that the Court had departed from its flawed reasoning in Posadas.$^{68}$ Second, the Court noted that the scope of any type of "vice exception," if it were to exist, would be practically impossible define.$^{69}$ Any "vice exception" would have also the effect of allowing legislatures to justify censorship by simply placing the label of "vice" on any activity it wishes to regulate. ${ }^{70}$ Finally, it would force the courts to develop a federal common law defining the scope of what "vice" actually entails. ${ }^{71}$

In 44 Liquormart, having abandoned the "greater power includes the lesser" doctrine, the Court applied the traditional Central Hudson analysis to the Rhode Island advertising restriction. ${ }^{72}$ The state argued that its advertising prohibition satisfied the Central Hudson test because it directly advanced the state's substantial interest in reducing alcohol consumption and because it was no more extensive than necessary. ${ }^{73}$ First, the Court held that the prohibition did not satisfy the "directness" requirement because the state failed to prove, beyond mere speculation, that the speech restriction would significantly reduce statewide alcohol consumption. ${ }^{74}$ Second, the court held that it would be impossible for the speech restriction to pass the "least restrictive means" prong of the Central Hudson test. ${ }^{75}$ This is because, where the government has the power to directly regulate an activity, any type of speech prohibition will be more restrictive than necessary. ${ }^{76}$ For instance, it would clearly be less restrictive if the state were to simply set baseline prices for liquor, or limit the amount that an individual could purchase. ${ }^{77}$ This would accomplish the same

67. Id. ("Our decision last Term striking down an alcohol-related advertising restriction effectively rejected the very contention respondents now make.”).

68. $I d$.

69. Id. at 514 ("Almost any product that poses some threat to public health or public morals might reasonably be characterized by a state legislature as a 'vice activity.' Such characterization, however, is anomalous when applied to products such as alcoholic beverages, lottery tickets, or playing cards, that might lawfully be purchased on the open market.").

70. Id.

71. Id.

72. 44 Liquormart, 512 U.S. at 504.

73. $I d$.

74. Id. at 507 .

75. $I d$.

76. $I d$.

77. 44 Liquormart, 512 U.S. at 507 (“As the State's own expert conceded, higher prices can be maintained either by direct regulation or by increased taxation. . . Per capita purchases could be limited as is the case with prescription drugs. Even educational campaigns focused on the problems of excessive, 
goal, that of promoting temperance, but would not offend the First Amendment. Thus, 44 Liquormart solidified the Supreme Court's stance against any kind of "vice exception" to the intermediate scrutiny of Central Hudson.

\section{The Ninth Circuit's Holding in Coyote Publishing, Inc. v. Miller}

In Coyote Publishing, Inc. v. Miller, the United States Court of Appeals for the Ninth Circuit upheld the constitutionality of a Nevada statute that restricted advertising pertaining to legal brothels. ${ }^{78}$ Nevada is the only state that allows for legal prostitution, giving each county within the state the option of allowing legal brothels to operate. ${ }^{79}$ Currently, eleven of Nevada's seventeen counties permit the operation of legal brothels. ${ }^{80}$ Though, interestingly enough, Nevada's largest city, Las Vegas, does not allow legal prostitution because the enabling statute prohibits the operation of legal brothels in counties with populations exceeding 400,000 people. ${ }^{81}$ Though the state legislature chose to legalize prostitution in select counties, it simultaneously placed severe restrictions on advertising regarding the activity. ${ }^{82}$ Nevada Revised Statute $\S 201.430$ prohibits any person acting on behalf of a legal brothel from advertising "in any public theatre, public street, or highway" or to include in "any display, handbill or publication [the] address, location or telephone number of a house of prostitution or of identification of a means of transportation to such a house. ${ }^{.83}$ Furthermore,

\footnotetext{
or even moderate, drinking might prove to be more effective.”).

78. Coyote Publishing Inc., 598 F.3d at 611.

79. Balboni, supra note 21 , at 558 .

80. Id.

81. Coyote Publishing, 598 F.3d at 596.

82. Balboni, supra note 21, at 558.

83. The statute provides:

1. It is unlawful for any person engaged in conduct which is unlawful pursuant to paragraph (b) of subsection 1 of NRS 207.030, or any owner, operator, agent or employee of a house of prostitution, or anyone acting on behalf of any such person, to advertise the unlawful conduct or any house of prostitution:

(a) In any public theater, on the public streets of any city or town, or on any public highway; or (b) In any county, city or town where prostitution is prohibited by local ordinance or where the licensing of a house of prostitution is prohibited by state statute.

2. It is unlawful for any person knowingly to prepare or print an advertisement concerning a house of prostitution not licensed for that purpose pursuant to NRS 244.345, or conduct which is unlawful pursuant to paragraph (b) of subsection 1 of NRS 207.030, in any county, city or town where prostitution is prohibited by local ordinance or where the licensing of a house of prostitution is prohibited by state statute.
} 
Nevada Revised Statute $\S 201.440$ provides criminal penalties up of to six months of imprisonment and up to $\$ 1,000$ in fines for violating the advertising prohibition. ${ }^{84}$ The petitioners, several local newspaper publishers, brought a facial challenge to the constitutionality of both of these statutory provisions. ${ }^{85}$ Applying the four-pronged Central Hudson test, the district court held that the state "failed to meet their burden of demonstrating that the provisions containing the prohibition of advertising for legal brothels on streets, highways and theatres throughout the State of Nevada is narrowly tailored to effectuate a substantial governmental interest." ${ }^{" 86}$ The respondents then appealed the decision to the Ninth Circuit Court of Appeals.

On appeal, the Ninth Circuit recognized that the statute clearly placed a restriction on commercial speech and correctly chose to employ the familiar Central Hudson analysis. ${ }^{87}$ Nevada did not assert that the advertising of prostitution was false, deceptive, or misleading, so the first prong of the Central Hudson test was easily satisfied. ${ }^{88}$ In regards to the legality of the activity, the court entertained Nevada's argument that prostitution was unlawful, at least in counties that prohibited it, but found that the activity was lawful at the state level.$^{89}$ Thus, finding that the statute restricted truthful, nonmisleading speech about a lawful activity, the court moved onto step two of the analysis. ${ }^{90}$

First, the court identified Nevada's substantial interest in restricting advertising for legal brothels as "limiting the commodification of sex." state had actually asserted that its substantial interest was "not allowing minors to learn of the existence of legal brothels." ${ }^{.92}$ However, the court gave

3. Inclusion in any display, handbill or publication of the address, location or telephone number of a house of prostitution or of identification of a means of transportation to such a house, or of directions telling how to obtain any such information, constitutes prima facie evidence of advertising for the purposes of this section.

Nev. Rev. Stat. § 201.430 (2011).

84. NeV. Rev. Stat. $§ 201.440$ (2011).

85. Coyote Publishing, 598 F.3d at 597.

86. Coyote Pub., Inc. v. Heller, No. CV06-329JCM-PAL, 2007 WL 2254702, at *5 (D. Nev. Aug. 3, 2007), rev'd sub nom. Coyote Pub., Inc. v. Miller, 598 F.3d 592 (9th Cir. 2010).

87. Coyote Publishing, 598 F.3d at 599.

88. Id. at 606

89. Id. at 607 ("It is consistent with fundamental precepts of our federal system that the law of jurisdiction where the transaction is proposed should govern the legality of those transactions, as citizens of one state ordinarily are free to travel to another state and have their behavior governed by the law of that second state.").

90. Id. at 608

91. Id.

92. Id. at 602 n. 14 ("We do not understand Nevada's argument to be so narrow. Nevada's opening 
this a broad reading and held that "the state's concern over sex commodifying advertisements goes beyond children to encompass society in general." 93 Applying the "directness" test to the asserted state interest against commodification of sex, the court held that the speech restriction directly and materially advanced the state's interest by (1) limiting advertisements that are in themselves an aspect of the commodifying of sex; and (2) by reducing the market demand for, and thus the incidence of, the exchange of sex acts for money. ${ }^{94}$

Finally, the court held that the speech restriction satisfied the least restrictive, "reasonable fit" prong of the Central Hudson analysis because "Nevada strikes a balance between its interest in maintaining economically viable, legal, regulated brothels and its interest in severely limiting the commodification of sex. ${ }^{" 95}$ Thus, because the court found that the advertising restriction satisfied the Central Hudson intermediate scrutiny test, the Nevada statute prohibiting advertisements for legal brothels was upheld by the Ninth Circuit. ${ }^{96}$

\section{The Holding in Coyote Publishing Failed to Correctly Apply the CENTRAL Hudson Analysis}

The Plaintiffs filed a Petition for a Writ of Certiorari on October 25, 2010. However, the Petition was denied. ${ }^{97}$ If the Supreme Court granted the Petition, it is likely that the decision would have been reversed, and the restrictive statute would have been struck down as a violation of the First Amendment. In Coyote Publishing, the court incorrectly interprets the ruling from 44 Liquormart and grants entirely too much deference to the legislature in restricting speech regarding legal prostitution. In its opinion, the Ninth Circuit expressly recognizes that there is no general "vice exception" to the protections accorded to commercial speech, however, it nevertheless goes on to create a new exception for commercial speech promoting houses of legal

\footnotetext{
brief explains that the advertising restrictions serve to 'limit prostitution's profile in society.' Thus although Nevada does not argue in particular that children should not be exposed to prostitution advertisements, the state's concern over sex commodifying advertisements goes beyond children to encompass society in general.”).

93. Coyote Publishing, 598 F.3d at 602 n.4.

94. Id. at 608 .

95. Id. at 610 .

96. Id. at 611 .

97. Coyote Publ'g., Inc. v. Masto, 131 S. Ct. 1556 (2011), denying cert. to sub nom. Coyote Publ'g., Inc. v. Miller, 598 F.3d 592 (9th Cir. 2010).
} 
prostitution..$^{98}$ Even though it expressly denies doing so, the Ninth Circuit inexplicably resurrects the overruled holding from Posadas.

The Supreme Court has explicitly rejected the idea of a "vice exception" to the Central Hudson analysis on at least three occasions since the Posadas decision. ${ }^{99}$ Even so, the Ninth Circuit goes on to create a specific exception for legal prostitution because of the particular evils with which it opines prostitution is associated. ${ }^{100}$ The social condemnation of prostitution, the court reasons, is vastly more widespread than for other categories of "vice" that courts have considered and that this "may be relevant to the degree of scrutiny applicable to these advertising restrictions." ${ }^{101}$ This is precisely the type of reasoning that the Supreme Court sought to prevent with its holding in 44 Liquormart. Almost any product that poses some threat to public health or morals could be characterized by the state legislature as a "vice activity," allowing legislatures to censor any advertising by simply placing a "vice" label on the activity. ${ }^{102}$ One can imagine a variety products or scenarios where the legislature could use a "vice exception" to justify its censorship. For example, a legislature could justify a ban on advertising for ice hockey or football games, labeling them "vice activities" because these sports often involve gambling and head injuries.

Subsequent to 44 Liquormart, in Lorillard, the Court reinforced its stance that no exception to the Central Hudson analysis should be granted simply because of the unique nature of a certain underlying activity, holding that "to uphold the Massachusetts tobacco regulations would be to accept a line of reasoning that would permit restrictions on advertising for a host of other products." 103 Thus, the Coyote Publishing court should not have granted the state legislature more deference simply because prostitution might be more widely condemned than other "vices" like alcohol consumption and casino gambling.

98. Coyote Publishing, 598 F.3d at 600.

99. 44 Liquormart, I517 U.S. at 511-12 (alcohol); Greater New Orleans Broad. Ass'n, Inc. v. United States, 527 U.S. 173, 195 (1999) (casino gaming); Lorillard, 533 U.S. at 566 (tobacco advertising).

100. Coyote Publishing, 598 F.3d at 600 ("We agree that there are strong reasons why the sale of sexual services, in particular, ought to be treated differently than other advertising bans on 'vice' activities.").

101. Id. at 601 .

102. 44 Liquormart, 512 U.S. at 514.

103. Lorillard, 533 U.S. at 586-87 (responding to the state's argument that "tobacco is in some sense sui generis - that it is so special, so unlike any other object of regulation, that application of normal First Amendment principles should be suspended"). 
By creating a sui generis exception to Central Hudson for legal prostitution, the Ninth Circuit is attempting to place a value judgment on a certain type of commercial speech. On several occasions, the Supreme Court has rejected the idea that, in determining the constitutionality of a speech restriction, a court should consider the relative costs and benefits of a certain type of speech. ${ }^{104}$ Most recently, in United States v. Stevens, the Court went so far as to strike down a speech restriction that prohibited the sale or possession of media depicting cruelty to animals. ${ }^{105}$ Though the state obviously had a substantial interest in preventing cruelty to animals, the statute was overly broad because it extended to other works of art and material that depicted hunting. ${ }^{106}$ In coming to this conclusion, the Court emphasized the danger of making value judgments when determining if a certain speech is protected under the First Amendment. ${ }^{107}$ The Court described such a system for First Amendment analysis as both "startling and dangerous" and held further that "[o]ur Constitution forecloses any attempt to revise that judgment simply on the basis that some speech is not worth it." 108 Though this case did not involve commercial speech, its underlying principles are similarly applicable to the case at hand because the Ninth Circuit engages in precisely the type of cost/benefit analysis dismissed by the Supreme Court.

In fact, the Ninth Circuit's decision in Coyote Publishing runs contrary to these well-established First Amendment principles. Moreover, the court contradicts itself many times over. It continually engages in the type of balancing exercise that was rejected by the Stevens court. For instance, the court quotes a passage from the Supreme Court's decision in Virginia State Bd. of Pharmacy v. Virginia Citizens Consumer Council, which held that "[a]dvertising, however tasteless and excessive it sometimes may seem, is nonetheless dissemination of information as to who is producing and selling what product, for what reason, and at what price ... to this end the free flow of commercial information is indispensable." 109 Nevertheless, the court immediately goes on to state that " $[\mathrm{w}]$ hen the underlying service is of extremely little value, as demonstrated by near consensus within our society,

104. See United States v. Stevens, 130 S. Ct. 1577, 1585 (2010); Hudnut v. Am. Booksellers Ass'n, Inc., 475 U.S. 1001 (1986).

105. Stevens, 130 S. Ct. at 1592.

106. Id.

107. Id. at 1585 .

108. Id.

109. Coyote Publishing, 598 F.3d at 601 (citing Virginia State Bd. of Pharmacy v. Virginia Citizens Consumer Council, Inc., 425 U.S. 748 (1976)). 
the need for its efficient allocation and distribution is less compelling." ${ }^{110}$ The Ninth Circuit first quotes a Supreme Court passage, which essentially holds that all commercial speech may be similarly valuable to society. However, it then argues that prostitution is of extremely little value, and thus its advertisements deserve less protection than for other activities. The Ninth Circuit's interpretation of Supreme Court precedent and its First Amendment analysis as it pertains to legal brothels are at complete odds with one another. Moreover, the court frequently places value judgments on the underlying activity, which should not enter into the First Amendment analysis.

To be fair, the Stevens Court also recognized that certain categories of speech may well deserve less protection than others. ${ }^{111}$ The Court noted its decision in New York v. Ferber, in which it held that child pornography is categorically unprotected under the First Amendment. ${ }^{112}$ However, in the case of child pornography, the Court did not engage solely in any type of simple cost-benefit analysis to determine that child pornography was not protected. ${ }^{113}$ Rather, the court emphasized that the underlying act (child abuse), was illegal in every jurisdiction in the United States. ${ }^{114}$ The court noted that "[i]t rarely has been suggested that the constitutional freedom for speech and press extends its immunity to speech or writing used as an integral part of conduct in violation of a valid criminal statute." 115 In the case of legal brothels, while the advertising may represent an integral part of the underlying act, the underlying act is not illegal. Therefore, at least in Nevada, advertising for legal brothels cannot simply be labeled as a type of speech that is categorically unprotected by the First Amendment.

The Ninth Circuit attempts to veil its obvious moral disfavor for legal prostitution by using economic arguments to explain why a sui generis exception for legal brothels should exist. ${ }^{116}$ It argues that one of the major policies behind the protection of commercial speech is the concern for the distortion of competitive economic markets. ${ }^{117}$ This is because commercial

110. Id

111. Stevens, 130 S. Ct. at $1585-86$.

112. Id. at 1586 .

113. Id.

114. Id.

115. Id.

116. Coyote Publishing, 598 F.3d at 601 ("The nature of the market in sexual services, such as it is, provides an additional reason why the goal of efficiency applies with less force. In light of prevailing sexual mores, a highly transparent, and thus efficient, market for sex is a chimera. In this respect, sex is not a commodity.").

117. Id. 
speech restrictions "tend to mitigate competition and maintain prices at a higher level than would prevail in a completely free market." ${ }^{118}$ The court then goes on to compare the market competition involved for legal brothels with that of the competition between electric companies in Central Hudson, concluding that, in the "context of the legal sale of sexual acts . . there is relatively little market competition to distort." ${ }^{119}$ However, Central Hudson and its progeny have never made a distinction that resulted in increased deference to the legislature based simply on the size of an affected market.

Moreover, the court provides no evidence to bolster its assumption that there is "relatively little market competition" in the legal brothel market. The decision in Central Hudson actually affected fewer corporate entities than does the Nevada commercial speech restriction, because only one electric company was operating in New York at the time. ${ }^{120}$ The Court even went so far as to specifically hold that "[e]ven in monopoly markets, the suppression of advertising reduces the information available for consumer decisions and thereby defeats the purpose of the First Amendment."121 Thus, the Supreme Court emphasizes the ability to disseminate truthful information, not the potential size or distortion of a given market. Consequently, this argument is not a justification for providing less First Amendment protection to a certain type of commercial speech. Furthermore, the decision in 44 Liquormart held expressly that Central Hudson First Amendment protection extends equally to all truthful speech about lawful activities. ${ }^{122}$

The court attempts to use this "lack of market distortion" concept as a way to lessen the protection afforded to advertising for legal brothels. That is, it contends that legal brothels deserve less First Amendment protection because prohibiting advertisements does not have a large effect on the market for legal prostitution. ${ }^{123}$ However, the Ninth Circuit misinterprets the Supreme Court's market distortion analysis. This concept has been more commonly used by the Court as a hurdle that the state must overcome in showing that it

118. Id. (citing 44 Liquormart, 517 U.S. at 502).

119. Id.

120. Central Hudson, 447 U.S. at 557.

121. Id. at 567.

122. 44 Liquormart, 517 U.S. at 503-04 (O’Connor, J., concurring) (“The commercial marketplace, like other spheres of our social and cultural life, provides a forum where ideas and information flourish. Some of the ideas and information are vital, some of slight worth. But the general rule is that the speaker and the audience, not the government, assess the value of the information presented. Thus, even a communication that does no more than propose a commercial transaction is entitled to the coverage of the First Amendment.").

123. Coyote Publishing, 598 F.3d at 601. 
has satisfied the "least restrictive means" criterion of the Central Hudson analysis, rather than as a mechanism for diminishing the importance of a certain type of advertising before even beginning the analysis. ${ }^{124}$

For instance, in 44 Liquormart, the Court held that the ban on advertising the price of liquor did not satisfy the final criterion because there was not a reasonable fit between the intended market effect and the means of preventing alcohol consumption employed by the state. ${ }^{125}$ Here, the state argued that its goal in prohibiting the advertisement of liquor prices was to promote temperance by preventing competition and keeping prices higher. ${ }^{126}$ However, the state conceded that such a goal could have been more easily accomplished by other types of market manipulation, such as direct regulation or taxation. ${ }^{127}$ Thus, the market distortion analysis has been used by the Supreme Court to assure a reasonable fit between the asserted state interest and the means employed to further that interest. However, the Ninth Circuit uses the concept to diminish the value of protecting a certain type of commercial speech, before even beginning the Central Hudson analysis.

Having established that no diminished scrutiny should apply because of legal prostitution's status as a "vice activity," it is now necessary to apply the standard Central Hudson four part analysis to the instant case. It soon becomes clear, that without the increased deference that the Ninth Circuit granted the Nevada legislature, the restrictive statute violates the Central Hudson test. First, though Nevada initially makes an argument that prostitution is illegal in certain counties, the court assumes that it is a lawful activity for purposes of argument. Presuming that the advertisements are also truthful, Central Hudson criterion number one falls in favor of the petitioners, and the burden is now shifted to the state to show that the statute directly advances a substantial state interest.

However, Nevada fails to meet the state's burden for the second prong of the Central Hudson analysis. It does not establish a substantial state interest. The first mistake made by the Ninth Circuit in its analysis was in creating a substantial interest not actually advanced by the state. The government bears the burden of showing a substantial interest and showing that is real, not hypothetical. ${ }^{128}$ Here, Nevada advanced the interest of "not allowing minors

124. See 44 Liquormart, 512 U.S. at 529; Rubin, 514 U.S. at 484.

125. 44 Liquormart, 512 U.S. at 507.

126. Id.

127. Id.

128. Playboy, 529 U.S. at 817. 
to learn of the existence of legal brothels." 129 This approach to justifying commercial speech bans has already been expressly disavowed by the Supreme Court. ${ }^{130}$ Lorillard made it clear that restrictive bans meant to protect only minors are overbroad if they also infringe too broadly upon advertising directed at adults. ${ }^{131}$ In the instant case, the Nevada statute imposes a near complete ban on advertising for legal brothels, which by definition are available only to adults over the age of 18 . Thus, the holding runs contrary to Lorillard in that even if "not allowing minors to learn of the existence of legal brothels" is a substantial state interest, the statute is overly broad because it prevents all adults from receiving almost any truthful information regarding legal brothels.

In order to evade the fairly direct holding of Lorillard, the Ninth Circuit takes the liberty of extending Nevada's substantial interest more generally to "preventing the commodification of sex." 132 In doing so, the Court advances a fairly incoherent explanation as to why this interest is substantial. The court begins its justification by stating, rather vaguely, that there is a deeply rooted American tradition that " $[\mathrm{t}]$ here are, in a civilized society, some things that money cannot buy." 133 It goes on to list examples, such as the Thirteenth Amendment, which outlawed slavery, as well as laws against receiving payment for adoptions and the sale of human organs. ${ }^{134}$ One must judge for himself or herself, whether these are sufficient justifications for deeming that the prevention of the "commodification of sex" is a substantial state interest. Regardless, it was improper for the court to create a substantial interest that was not advanced by the state because, under Central Hudson, the state bears the burden of showing that the interest is substantial. ${ }^{135}$

Even if preventing the "commodification of sex" is considered a substantial state interest, the Nevada statute still fails the third prong of the Central Hudson test, that the speech restriction directly advance the

129. Coyote Publishing, 598 F.3d at 602 n.14.

130. Lorillard, 533 U.S. at 564-65.

131. Id. ("The State's interest in preventing underage tobacco use is substantial, and even compelling, but it is no less true that the sale and use of tobacco products by adults is a legal activity. We must consider that tobacco retailers and manufacturers have an interest in conveying truthful information about their products to adults, and adults have a corresponding interest in receiving truthful information about tobacco products. In a case involving indecent speech on the Internet we explained that 'the governmental interest in protecting children from harmful materials ... does not justify an unnecessarily broad suppression of speech addressed to adults."').

132. See Coyote Publishing, 598 F.3d at 602 n.14.

133. Id. at 603 (quoting In re Baby M, 537 A.2d 1227, 1249 (1988)).

134. $I d$.

135. Playboy, 529 U.S. at 817. 
substantial interest, and there exists a reasonable fit between the advancement of the interest and the means chosen to advance that interest. ${ }^{136}$ As in Rubin, the entire regulatory scheme suffers from irrationality. ${ }^{137}$ It seems irrational to regulate and license legal brothels, yet still purport to have a substantial interest in preventing the commodification of sex. A legislature cannot create a scheme for the regulated sale of sex and simultaneously claim to advance a substantial interest in preventing such commodification. This is precisely the same problem the Court found with the alcohol content labeling ban in Rubin. Within the same statutory scheme, Nevada both licenses houses of prostitution and prohibits their advertisement almost completely. The statute that allows the licensing of legal brothels directly counteracts the aim of the statute, which bans their advertisement almost completely. As in Rubin, the Nevada restriction fails the "directness" test because of its inherent irrationality. ${ }^{138}$ Furthermore, the state failed to show beyond "mere speculation" that the restriction would, in fact, prevent further commodification of sex. ${ }^{139}$ Thus, the third prong of Central Hudson is not satisfied.

Finally, the Nevada statute also fails the "least restrictive means" test from Central Hudson. Here, as in Lorillard, the restriction constitutes almost a complete ban on advertising for legal brothels and should therefore be reviewed with careful scrutiny to ensure that the ban is not more restrictive than necessary. ${ }^{140}$ The government must prove the absence of any means less restrictive to the exercise of free speech. ${ }^{141}$ Here, as in 44 Liquormart, there are clearly means less restrictive on free speech that would serve the same substantial state interest. ${ }^{142}$ Thus, it is impossible for the restriction to pass the fourth prong of the Central Hudson test. Where a legislature has the power to directly regulate an activity, any regulation on speech concerning that activity will always be more restrictive than necessary. ${ }^{143}$ Therefore, the Nevada ban

136. Lorillard, 533 U.S. at 556.

137. Rubin, 514 U.S. at 488 (holding that the "[I] rrationality of this unique and puzzling regulatory framework ensures that the labeling ban will fail to achieve that end. There is little chance that $\S 205(\mathrm{e})(2)$ can directly and materially advance its aim, while other provisions of the same Act directly undermine and counteract its effects.").

138. Id.

139. Id. at 487 .

140. Lorillard, 533 U.S. at 556 ("In some geographical areas, these regulations would constitute nearly a complete ban on the communication of truthful information about smokeless tobacco and cigars to adult consumers. The breadth and scope of the regulations, and the process by which the Attorney General adopted the regulations, do not demonstrate a careful calculation of the speech interests involved.").

141. Id. at 561 .

142. 44 Liquormart, 512 U.S. at 507.

143. Id. 
on advertising for legal brothels is unconstitutional under the Central Hudson test.

If Nevada is truly interested in preventing the further commodification of sex, then it could follow the forty-nine other states in completely outlawing prostitution. Unless Nevada chooses to use its direct regulatory power to prohibit prostitution, it cannot constitutionally restrict truthful, non-misleading commercial speech concerning what is currently a lawful activity within the state

\section{CONCLUSION}

Nevada has chosen to engage in an experiment. In an attempt to cure the ills of illegal prostitution, it has set up a system for licensing legal brothels. In theory, this would help to eliminate the illegal and inherently dangerous underworld of prostitution within Nevada and prevent the abuse of women who choose to enter the profession. If all potential customers chose to use legal brothels, then the state would be able to effectively regulate the industry. However, this system cannot be fully realized unless it is allowed to operate and advertise consistently with other competitive businesses in the state. In order for a market to operate freely and efficiently, consumers must be fully and fairly informed of their options in order to make logical choices. In the case of prostitution, a customer might choose the services of an illegal unlicensed prostitute over that of a legal brothel because he is not well enough informed. This perpetuates the abusive system of illegal prostitution, as well as exposing the potential customer to the many inherent dangers of entering the criminal realm. If properly informed by commercial advertisements, all potential customers might choose to employ the services of legal brothels, and Nevada's statutory scheme could be effectively operated. Under the current system, this is not, and cannot be the case.

The Supreme Court certainly did not have legal prostitution in mind when it made its seminal decision in Central Hudson. However, the same principles apply. Truthful speech about lawful activities is afforded intermediate protection under the First Amendment. The Ninth Circuit Court of Appeals failed to correctly apply this level of scrutiny. Though the plaintiffs' Petition for Certiorari was recently denied by the Supreme Court on February 22, 2011, Central Hudson and its progeny indicate that the Court would have 
reversed the Ninth Circuit's decision and held that the Nevada ban on advertising for legal brothels is invalid on its face. ${ }^{144}$ 